\title{
Stability evaluation of organic Lip Balm
}

\author{
Alessandra Ribeiro Fernandes, Michelli Ferrera Dario, Claudinéia Aparecida Sales de Oliveira \\ Pinto, Telma Mary Kaneko, André Rolim Baby, Maria Valéria Robles Velasco*
}

\author{
Department of Pharmacy, Faculty of Pharmaceutical Sciences, University of São Paulo
}

\begin{abstract}
Rising global demand for natural products whose production is harmless to the environment has stimulated the development of natural cosmetics and, within this category, organics ( $95 \%$ organic raw materials). The image of environmentally friendly production is one of the strongest attractions of organic products. Lip balm is a cosmetic product similar to lipstick whose purpose is to prevent lip dryness and protect against adverse environmental factors. The product's characteristics are: resistance to temperature variations, pleasant flavor, innocuousness, smoothness during application, adherence and easy intentional removal. This work involved the development of a lip balm formulated with certified organic raw materials and the execution of stability tests: fusion point determination, evaluation of organoleptic characteristics (color, odor and appearance) and functionality evaluation (spreadability test). The formulation selected after the Preliminary Stability Test was submitted to the Normal Stability Test under the following storage conditions (temperature): Room Temperature $\left(22.0 \pm 3.0^{\circ} \mathrm{C}\right)$, Oven $\left(40.0 \pm 2.0^{\circ} \mathrm{C}\right)$ and Refrigerator $(5.0$ $\pm 1.0^{\circ} \mathrm{C}$ ), for 90 days. Under the Refrigerator and Room Temperature conditions, spreadability proved adequate, but the surface presented white spots, characterizing the fat bloom, a phenomenon involving the recrystallization of cocoa butter. Storage at $40.0 \pm 2.0^{\circ} \mathrm{C}$ (Oven) caused loss of functionality according to the spreadability test, in addition to changes in color, although the aspect was uniform since the fat bloom was not observed (white spots on the surface). The odor remained stable under all conditions as did the melting point, which had a mean of $72.9 \pm 1.7^{\circ} \mathrm{C}$ throughout the course of stability testing (90 days).
\end{abstract}

Uniterms: Lip balm. Stability. Cocoa butter. Cosmetic. Organic.

O aumento da demanda global por produtos naturais, cuja produção não envolva nenhum dano ao meio ambiente, tem estimulado o desenvolvimento de cosméticos naturais e, dentro desta categoria, dos produtos orgânicos (que contêm $95 \%$ de matérias-primas orgânicas). O protetor labial é um produto cosmético semelhante ao batom que tem a finalidade de prevenir o ressecamento dos lábios, mantendo a hidratação, e protegê-los contra fatores ambientais adversos. Este trabalho envolveu o desenvolvimento de um protetor labial formulado com matérias-primas orgânicas e avaliação dos parâmetros de estabilidade, como ponto de fusão, características organolépticas e funcionalidade (teste de espalhabilidade). A formulação selecionada após o Estudo de Estabilidade Preliminar foi submetida à Avaliação Normal de Estabilidade, nas seguintes condições de armazenamento (temperatura): Ambiente $\left(22,0 \pm 3,0^{\circ} \mathrm{C}\right)$, Estufa $\left(40,0 \pm 2,0^{\circ} \mathrm{C}\right)$ e Geladeira $\left(5,0 \pm 1,0^{\circ} \mathrm{C}\right)$, por 90 dias. Nas condições de armazenamento em geladeira ou ambiente, a espalhabilidade foi adequada, mas a superfície apresentou pontos esbranquiçados, caracterizando o fenômeno chamado fat bloom, que está relacionado à recristalização da manteiga de cacau. $\mathrm{O}$ armazenamento à temperatura elevada $\left(40,0 \pm 2,0^{\circ} \mathrm{C}\right)$ provocou perda de funcionalidade, de acordo com o teste de espalhabilidade, e mudança de cor, apesar do aspecto permanecer uniforme, visto que não foi observado o fenômeno fat bloom. O odor manteve-se estável em todas as condições, assim como o ponto de fusão, com valor médio de $72,9^{\circ} \mathrm{C} \pm 1,7^{\circ} \mathrm{C}$ durante todo o período de avaliação do teste de estabilidade (90 dias).

Unitermos: Protetor labial. Estabilidade. Manteiga de cacau. Cosmético. Orgânico.

*Correspondence: M.V.R. Velasco. Departamento de Farmácia, Faculdade de Ciências Farmacêuticas, Universidade de São Paulo. Av. Prof. Lineu Prestes, n.580, B1-13/15, 05508-000 - São Paulo - SP, Brasil. E-mail: mvrobles@usp.br 


\section{INTRODUCTION}

\section{Organic cosmetics}

Raw materials and products certified as organic are produced in an agricultural system that ensures balanced management of the soil and other natural resources. Organic farming follows strict rules for certification, which prohibit the use of pesticides, require preservation of natural resources and ensures adequate conditions of work in the field (IBD, 2007).

The success of organic products occurs predominantly in the food area. Customers have the perception that these products are beneficial to health and are environmentally friendly. The same principles apply to the cosmetic area.

In Brazil, there is no specific legislation for products declared natural or organic. Such certification is done by national and international organizations. The main national organization is the IBD (Associação de Certificação Instituto Biodinâmico) while the international organ is the IFOAM (International Federation of Organic Agriculture Movements), both of which certify organic food and have recently started certifying cosmetics (IBD, 2007; IFOAM, 2008).

Natural products are not necessarily organic. To be considered as such, more specific farming and production criteria must be met. The following list contains classification criteria of natural or organic products for certification (IBD, 2007).

a. $100 \%$ Organic: all ingredients are certified as organics (this classification is used only in the USA legislation);

b. Organic Product: at least 95\% organics;

c. Product with organic ingredients: between 70 and $95 \%$ organics;

d. Only a list of ingredients indicating organics: between 50 and $70 \%$ organics;

e. Natural: at least $5 \%$ organics.

Therefore, to be certified as Organic, the cosmetic product must be formulated with at least $95 \%$ organic raw materials; preserve the original qualities of the raw materials in natura; have minimal impact on the environment during their production, use and disposal; provide clear labeling for consumer advice; must not be tested on animals and be safe for use in humans (IBD, 2007).

Natural products have gained importance in the cosmetic market, with predicted output growth of between 20 and $30 \%$ per year in Brazil and $80 \%$ per year worldwide
(ABIHPEC, 2005). Within this product category, organics represent a special category because products with organic certification have a "green" or "environmentally friendly" claim which is much stronger than that of natural products. This claim is used as a means of product differentiation in the market. Products with organic claims grew $273 \%$ in the United States in the 2005-2007 period, while products with the claim of being natural increased $71 \%$ (Bishop, 2008).

\section{Lip balm}

Lip balms are formulations applied onto the lips to prevent drying and protect against adverse environmental factors. The cosmetic literature reports scant data on this type of formulation, although references related to lipstick apply because it is a cosmetic form similar to lip balm (stick form). This similarity extends to include organoleptic and stability requirements, such as resistance to temperature variations, pleasant taste, innocuousness, smoothness during application, adherence and easy intentional removal (Denavarre, 1975; Gouvea, 2007). Lip balm should not be considered equivalent to the lip gloss, with the former being a product intended for use by both men and women.

The main ingredients of lipstick are fatty acids, such as waxes, oils and butters, which provide consistency and work as emollients in the preparations. Among these, castor oil, beeswax, carnauba wax, candelilla wax, paraffin and cocoa butter are often used. Lipstick also contains additives, such as antioxidants, conservatives and fragrances, as well as dyes and pigments (Denavarre, 1975; Barel et al., 2001).

There are however, a few significant differences between lipstick and lip balm, especially regarding functionality where lipstick is used to impart color to the lips whereas lip balm provides protection. Furthermore, lipstick formulations are of greater complexity due to a larger number of ingredients compared to lip balm formulations.

To formulate lip balms, it is necessary to balance the concentration of the main ingredients including butters, oils and waxes, so that the final product presents an adequate fusion point of between 65 and $75^{\circ} \mathrm{C}$ (Gouvea, 1993; Bonadeo, 1982). Depending on the proportion of wax, oils and pigments, the formulation will present different characteristics. A long-wearing product may be obtained by employing a high proportion of wax and pigment, while the opposite will produce a smoother lipstick or lip balm (Cunninghan, 1996). Thus, contact of the product with the skin will not cause a sensation of friction or dryness, and should allow the forming of a homogeneous layer over the lips in order to protect the 
labial mucous susceptible to environmental factors such as UV radiation, dryness and pollution.

The ingredients used in a formulation like lip balm can have an undesirable effect on softening and rupture points, characteristics independent of each other. Two distinct formulations can have the same fusion point but different consistencies. These flaws can demand significant effort from the formulator to remedy. A balance between the ingredients of the formula must be achieved in order for the formulation to have acceptable fusion, softening and rupture points (Gouvea, 1993).

The technique used to manipulate the raw materials that comprise conventional lipstick is of extreme importance to the final result. Excluding the step of dye dispersion, which is not applicable to lip balm, the technique consists basically of mixing the solid fat components, which are heated until fusion, adding the liquid oils and then molding. The moderate mixture agitation allows the exit of any trapped air. This and other technical details, especially during the heating and molding phases, have a major impact on the final product. Signs of instability such as aeration, deformation and cracking may result from inadequate preparation (Denavarre, 1975).

Akin to the global cosmetics industry, which conducts research on new product options including natural and highly organic formulations, the aim of this work was to evaluate the preliminary and normal stability of an organic lip balm formulation developed based on an innovative and ecologically oriented concept.

\section{MATERIAL AND METHODS}

\section{Material}

The organic raw materials ( $95 \%$ of the formulation), certified by the IBD, were provided by Valeso Especiarias Orgânicas Ldta.: cocoa butter, carnauba wax, palms butter and sweet almond oil. The following raw materials (5\% of the formulation) not certified as organics were: soy lecithin (Polytechno Indústrias Químicas Ltda.), benzoic acid (Polypharma S.A.) and vitamin E (Roche ${ }^{\circledR}$ ). The qualitative composition of the organic lip balm developed is given in Table I.

\section{METHODS}

\section{Preparation of organic lip balm}

The raw materials were weighed on a balance accurate to the nearest $0.01 \mathrm{~g}$ to prepare a quantity of 50 $\mathrm{g}$ in a glass beaker.
TABLE I - Qualitative composition of organic lip balm developed

\begin{tabular}{ll}
\hline \multirow{3}{*}{ Component } & Function in formulation \\
& (BONO et al., 2006; MERCK \\
& Index, 2006) \\
\hline
\end{tabular}

Cocoa butter (Theobroma Hydrating, reduces melting point cocoa)

Carnauba wax (Copernicia Increases viscosity and melting prunifera) point

Palm butters (Arecaceae $s p$ ) Hydrating, reduces melting point Sweet almond oil (Prunus Emollient, reduces viscosity amygdalus)

Soy lecithin

Benzoic acid Reduces viscosity

Vitamin E

Preservative

Antioxidant

The preparation technique consisted of heating the solid raw materials in a controlled manner with an indirect flame until complete melting and homogenization to a maximum temperature of $90.0^{\circ} \mathrm{C}$. Subsequently, vitamin E, sweet almond oil and previously dissolved benzoic acid were added at $\pm 87.0^{\circ} \mathrm{C}$.

After homogenizing, the mixture was maintained at $87.0^{\circ} \mathrm{C}$ to allow molding of the lip balm at a temperature of at least $1.0^{\circ} \mathrm{C}$ above the melting temperature of the component with the highest melting point, in this case, carnauba wax of approximately $86.0^{\circ} \mathrm{C}$ (Gouvea, 1993). The lip balm was poured into lip stick packaging, a round plastic case with an elevator system, and the product was then refrigerated $\left(5.0 \pm 1.0{ }^{\circ} \mathrm{C}\right)$ for at least one hour and stored at room temperature for 48 hours to stabilize the preparation.

\section{Preliminary stability study}

The formulation developed was evaluated on Preliminary Stability Tests which included organoleptic characteristics (color, odor and appearance) and spreadability, over at least three days at room temperature $\left(22.0 \pm 3.0^{\circ} \mathrm{C}\right)$ and oven temperature $\left(40.0 \pm 2.0^{\circ} \mathrm{C}\right)$. As this type of cosmetic form undergoes softening and deformation at temperatures over $50^{\circ} \mathrm{C}$, the oven condition was chosen as the highest temperature of the stability study (Gouvea, 1993; Brasil, 2004). As this formulation exhibited no organoleptic or spreadability changes, it was submitted to Normal Stability Study.

\section{Normal stability study}

The Stability Test of a lipstick usually begins 24 or 
48 hours after preparation, a time described in the literature as sufficient to stabilize the formulation (Gouvea, 1993; Oliveira, 2003).

A quantity of $350 \mathrm{~g}$ of the formulation was prepared for the Normal Stability Test, in which the organoleptic characteristics (color, odor, appearance), spreadability and melting point were evaluated for 90 days under the conditions of Room Temperature (RT, $22.0 \pm 3.0^{\circ} \mathrm{C}$ ), Oven $\left(\mathrm{O}, 40.0 \pm 2.0^{\circ} \mathrm{C}\right)$ and Refrigerator $\left(\mathrm{Re}, 5.0 \pm 1.0^{\circ} \mathrm{C}\right.$ ) (Brasil, 2004). The samples were stored as indicated in duplicates.

The formulation was stored at room temperature $\left(22.0 \pm 3.0^{\circ} \mathrm{C}\right)$ for 48 hours and then evaluated at baseline $\left(\mathrm{t}_{0}\right)$ (Brasil, 2004). It was then stored under different conditions, according to the Normal Stability Study, and characteristics assessed on the $3^{\text {rd }}, 7^{\text {th }}, 15^{\text {th }}, 30^{\text {th }}, 60^{\text {th }}$ and $90^{\text {th }}$ days. Assessments at $t_{0}$ were considered as a reference for comparing the results.

\section{Melting point}

To determine the melting point, the material was made molten to fill capillaries (duplicate). The capillaries were coupled to a system with a thermometer and immersed in a vial with water at a controlled temperature. The temperature at which melting of the lip balm sample was observed was considered the melting point (Gouvea, 1993).

\section{Organoleptic characteristics}

Color and appearance were characterized visually with a loupe of $10 \mathrm{x}$ magnification while the odor was compared by the evaluator. The criteria described below were established by the evaluator to determine organoleptic characteristics, with samples analyzed in duplicate during the predetermined time for each condition, and compared against a freshly prepared formulation at $\mathrm{t}_{0}$ :

N-Normal;

M - Modified;

IM - Intensely Modified.

\section{Test of spreadability}

The test of spreadability consisted of applying the product (at room temperature of $22.0 \pm 3.0^{\circ} \mathrm{C}$ ) repeatedly onto a glass slide to visually observe the uniformity in the formation of the protective layer and whether the stick fragmented, deformed or broke during application. For this test, the following criteria were established by the analyst: G - Good: uniform, does not leave fragments; perfect application, without deformation of the lip balm;
I - Intermediate: uniform; leaves few fragments; appropriate application; little deformation of the lip balm; B - Bad: not uniform; leaves many fragments; difficult or inappropriate application, intense deformation of the lip balm.

\section{RESULTS}

\section{Preliminary study of stability}

The formulation developed showed appropriate organoleptic characteristics (color light yellow, odor characteristic of almond oil and uniform aspect) and solidified at the temperature of $40^{\circ} \mathrm{C}$ without deformation.

\section{Normal stability test}

Table II depicts the results of the Normal Stability Test, in which color, odor, appearance, spreadability and melting point of the formulation were evaluated.

The melting point remained stable throughout the stability test and had a mean of $72.9 \pm 1.7^{\circ} \mathrm{C}$.

The color of the formulation was considered stable under Room Temperature and Refrigerator conditions, but there were changes under the Oven condition, from light-yellow to darker yellow, classified as modified in Table II. It was observed that the formulation previously stored in the Oven, after being kept for about three days at room temperature, began to take on a light-yellow color and consistency similar to samples stored at Room Temperature and under Refrigerator conditions. Therefore, it was evident that this formulation of organic lip balm needed more time to fully stabilize after being subjected to a temperature of $40.0 \pm 2.0^{\circ} \mathrm{C}$.

The odor, characteristic of almond oil, remained stable throughout the 90 days of testing under all conditions evaluated.

By contrast, for the color assessment, the visual aspect was considered uniform under the Oven condition, while under Refrigerator and Room Temperature conditions, the presence of some white spots (fat bloom) was observed on the surface of the lip balm from the third evaluation day onwards.

The spreadability was considered good for the formulations stored at Room Temperature and under Refrigerator conditions, given they showed uniformity upon application without fragmenting or deforming of the stick, throughout the Stability Test. Under the Oven condition, the lip balm material presented a soft consistency, impairing spreadability and deforming the stick during the test. 
TABLE II - Evaluation of organoleptic characteristics, spreadability and melting point of lip balm formulation in Normal Stability Study

\begin{tabular}{|c|c|c|c|c|c|c|c|c|c|c|c|c|c|c|c|c|c|c|c|}
\hline \multirow{3}{*}{ Parameters* } & \multirow{3}{*}{$\mathrm{t}_{0}$} & \multicolumn{18}{|c|}{ Storage Conditions } \\
\hline & & \multicolumn{6}{|c|}{$\mathbf{R e}$} & \multicolumn{6}{|c|}{ RT } & \multicolumn{6}{|c|}{$\mathbf{O}$} \\
\hline & & \multicolumn{18}{|c|}{ Time (days) } \\
\hline Aspect & Uniform & M & M & M & M & M & M & M & I M & M & IM & M & M & $\mathrm{N}$ & $\mathrm{N}$ & $\mathrm{N}$ & $\mathrm{N}$ & $\mathrm{N}$ & $\mathrm{N}$ \\
\hline Color & Light yellow & $\mathrm{N}$ & $\mathrm{N}$ & $\mathrm{N}$ & $\mathrm{N}$ & $\mathrm{N}$ & $\mathrm{N}$ & $\mathrm{N}$ & $\mathrm{N}$ & $\mathrm{N}$ & $\mathrm{N}$ & $\mathrm{N}$ & $\mathrm{N}$ & M & M & M & M & M & M \\
\hline $\mathrm{MP} * *\left({ }^{\circ} \mathrm{C}\right) \pm$ & $72.0 \pm 0.0$ & \multicolumn{6}{|c|}{$72.5 \pm 75.8 \pm 73.2 \pm 71.8 \pm 72.8 \pm 73.2 \pm$} & \multicolumn{6}{|c|}{$76.0 \pm 70.8 \pm 70.5 \pm 73.0 \pm 71.5 \pm 71.5 \pm$} & \multicolumn{6}{|c|}{$76.0 \pm 72.5 \pm 73.0 \pm 74.0 \pm 74.5 \pm 72.5 \pm$} \\
\hline $\mathrm{CV}^{* * *}$ & & 0.5 & 0.3 & 0.3 & 0.3 & 0.8 & 0.8 & 0.5 & 1.8 & 0.5 & 1.0 & 0.5 & 0.5 & 2.0 & 0.5 & 1.0 & 0.0 & 1.0 & 0.5 \\
\hline
\end{tabular}

*All parameters were evaluated in duplicate

$\mathbf{t}_{\mathbf{0}}$ : Preparation of the formulation after $48 \mathrm{~h}$

Conditions: $\mathbf{R e}-$ Refrigerator $\left(5.0 \pm 1.0^{\circ} \mathrm{C}\right)$; RT - Room temperature $\left(22.0 \pm 3.0^{\circ} \mathrm{C}\right)$; $\mathbf{O}-\mathrm{Oven}\left(40.0 \pm 2.0^{\circ} \mathrm{C}\right)$;

Aspect, Color and Odor: N - Normal; M - Modified; IM - Intensely modified;

Spreadability: G - Good; I - Intermediate; B - Bad;

**MP - Melting Point: mean of two determinations.

$* * * \mathrm{CV}-$ Coefficient of variation

\section{DISCUSSION}

Consumers concerned with the environment are willing to spend more on "environmentally friendly" products, favoring the growth of the market for organic cosmetics. Following this trend, cosmetic manufacturers have invested in research and development of this product category. However, the development of organic cosmetics poses major technical challenges in that, besides requiring experience and skill of the formulator, there is a restriction on the use of raw materials, since $95 \%$ of the formulation must be of organic origin.

Studies of stability of cosmetic formulations are carried out in order to predict the possible physical, physicochemical and chemical changes that may occur from product manufacture through to the end of its shelf life. Stability studies are useful as a screening tool for all potential manifestations of instability of a formulation, even if they never occur under conditions of product use. Furthermore, possible changes in the product can be identified before it is released for use by consumers (Barel et al., 2001; Brasil, 2004).

In the stability test, the formulations are subjected to different conditions of temperature in order to assess changes over time. Usually the formulations are stored at room temperature, at elevated temperatures (at 37, 40, 45 or $50 \pm 2{ }^{\circ} \mathrm{C}$ ) and low temperatures (in the refrigerator at $5{ }^{\circ} \mathrm{C}$ and/or freezer at -5 or $-10 \pm 2{ }^{\circ} \mathrm{C}$ ). The storage temperatures selected for evaluation depend on the conditions to which the preparation may be submitted when sold and the particular characteristics of each formulation (Brasil, 2004).

The development of organic cosmetics is a challenge, mainly because it involves scant availability of organic raw materials in the market able to replace the non-organic components typically incorporated to stabilize preparations. The preservative (benzoic acid) and antioxidant (vitamin E) were selected among others found in the list of non-organic raw materials permitted (maximum concentration 5\%), because they have good compatibility with other components of the formulation (IBD, 2006).

Although the compatibility of all components in the formulation represents an important factor affecting the stability of a lipstick or lip balm, it is also essential to study the spreadability parameter which, in turn, is influenced by melting point. This parameter may be adjusted in a lip balm formulation by balancing the proportion of cocoa butter and carnauba wax, raw materials commonly used in this kind of formulation. Increasing the proportion of wax in relation to cocoa butter causes both an elevation in melting point and hardness, facilitating stick breakage (Gouvea, 1993). The hardness influenced by wax is due to the presence of esters of hydroxylated unsaturated fatty acids with twelve carbon atoms in the acid chain (Merck index, 2006).

According to the literature, which reports an appropriate melting point of between 65 and $75{ }^{\circ} \mathrm{C}$ (Gouvea, 1993; Bonadeo, 1982), the tested formulation was adequate (mean melting point of $72.9 \pm 1.7^{\circ} \mathrm{C}$ ), 
regardless of storage condition, according to the values described in Table II.

The fat bloom was observed on the surface of the organic lip balm from the third day of the Stability Test onwards, a result indicated in Table II as modified since at $\mathrm{t}_{0}$ the aspect was uniform. The fat bloom phenomenon consists of the formation of large fat crystals on the surface of the product, resulting in a whitish appearance. The mechanism of bloom formation is not fully understood, although is known to be related to the crystalline forms of cocoa butter and/or a phase separation of the triglycerides within the crystalline structure of the cocoa butter. The fat bloom can be considered the result of migration of the liquid fraction of fat within the matrix and its gradual uncontrolled recrystallization on the surface (Foubert et al., 2001).

There are at least six types of polymorphisms of cocoa butter described in the literature, four of which, called $\gamma, \alpha, \beta$ ' and $\beta$, have melting points of about $17,23,28$, and $35^{\circ} \mathrm{C}$, respectively. Therefore, after homogenization of the components, the cooling of the preparation must be controlled in order to induce the formation of stable crystals $(\beta)$ of cocoa butter, which have a higher melting point $\left(35.0^{\circ} \mathrm{C}\right)$. One way of inducing the formation of stable crystals of cocoa butter is by reheating the formulation at lower temperatures $\left(32.0 \pm 2.0^{\circ} \mathrm{C}\right)$. Thus, the unstable crystals $\left(\gamma, \alpha, \beta^{\prime}\right)$ with lower melting points are recrystallized into a stable form $(\beta)$ (Willie, Lutton, 1996; Cohen, 2004; Richter, Lannes, 2007).

The Normal Stability Test allowed the identification of particular aspects of the studied cosmetic formulation that influence its stabilization. To avoid the formation of fat bloom, storage of the preparation at $32^{\circ} \mathrm{C}$ is suggested, before final storage at room temperature. In addition, the settling time of the product to begin the stability test should be extended beyond 48 hours to allow complete stabilization of the crystals of cocoa butter and hence the stabilization of the formulation of organic lip balm (Willie, Lutton, 1996; Cohen et al., 2004).

The scientific literature usually recommends 24 or 48 hours for initial assessment of a lipstick (Gouvea, 1993; Oliveira, 2003). However, for this formulation of organic lip balm, a period of 72 hours is suggested, as the spreadability of the product improved from "Intermediate" to "Good", according to the pre-established evaluation criteria, from the third day onwards.

\section{CONCLUSIONS}

During the Stability Test, the developed formulation of organic lip balm exhibited an appropriate melting point (mean of $72.9 \pm 1.7^{\circ} \mathrm{C}$ ), regardless of storage conditions, showing that the composition and ratio of cocoa butter and carnauba wax was adequate.

According to results of the spreadability tests, a period of 72 hours is recommended to complete stabilization of this formulation. Furthermore, storage in the Oven $\left(40.0 \pm 2.0^{\circ} \mathrm{C}\right)$ is not recommended because of loss of product functionality observed during the Normal Stability Test. However, the formulations stored under this condition were found to return to baseline characteristics after about 72 hours at room temperature.

The formulations stored at Refrigerator and Room Temperature showed similar behavior during the Normal Stability Test. The organoleptic characteristics were stable and spreadability was evaluated as "Good." Storage under these conditions was considered adequate, particularly because the functionality of the product was maintained.

\section{ACKNOWLEDGMENTS}

We would like to thank Valeso Especiarias Orgânicas Ldta for the technical support, Fernanda Daud Sarruf for her contribution and the Conselho Nacional de Desenvolvimento Científico e Tecnológico (CNPq) for financial support.

\section{REFERENCES}

ABIHPEC. Associação Brasileira da Indústria de Higiene Pessoal Perfumaria e Cosméticos. Cosméticos são a nova aposta dos orgânicos. Available at: http://www.abihpec.org. br/noticias_texto.php?id=335. Accessed on: 2 nov. 2008.

BAREL, A.O.; PAYE, M.; MAIBACH, H.I. Handbook of cosmetic science and technology. New York: Marcel Dekker, 2001. 904 p.

BISPO, M. Cosméticos verdadeiramente orgânicos. Cosmet. Toiletries (Portuguese edition), v.20, n.5, p.50-52, 2008.

BONADEO, I. Cosmetica ciencia y tecnología. Madrid: Ciencia SA, 1982. p.347-356.

BONO, A.; MUN, H.C.; RAJIN, M. Effect of various formulation on viscosity and melting point of natural ingredient based lipstick. Stud. Surf. Sci. Catal., v.159, p.693-696, 2006.

BRASIL. Ministério da Saúde. Agência Nacional de Vigilância Sanitária. Séries Temáticas: Qualidade 1. Guia de Estabilidade de produtos cosméticos. Brasília, v.1, 2004. $45 \mathrm{p}$. 
COHEN, K.O.; LUCCAS, V.; JACKIX, M.N.H. Revisão: temperagem ou pré-cristalização do chocolate. Braz. J. Food Technol., v.7, p.23-30, 2004.

CUNNINGHAN, J. Color cosmetics. In: WILLIAMS, D.F. Chemistry and technology of the cosmetics and toiletries industry. London: Chapman and Hall, 1996. cap.4, p.149158.

DENAVARRE, M.G. The chemistry and manufacture of cosmetics. 2.ed. Orlando: Continental Press, 1975. v.3, p.699.

FOUBERT, I.; CAUTEREN, I.V.; DEWETTINCK, K.; HUYGHEBAERT, A. Differential scanning calorimetry as a means of predicting chocolate fat-blooming. In: WIDLAK, N.; HARTEL, R.; NARINE, S. (Eds.). Crystallization and solidification properties of lipids. United States of American: AOCS Press, 2001. cap.6, p.79-86.

GOUVEA, M.C.B.L.F. Desenvolvimento de base de batons. Cosmet. Toiletries (Portuguese edition), v.5, n.2, p.49-56, 1993.

GOUVEA, M.C.B.L.F. Evolução na formulação de batons. Cosmet. Toiletries (Portuguese edition), v.19, n.2, p.72-75, 2007.
IBD. Instituto Biodinâmico. Diretrizes para a certificação de produtos de saúde e beleza orgânicos e naturais e para matérias primas orgânicas e naturais. 1.ed., 2007. Available at: www.ibd.com.br. Accessed on: 04 mar. 2008.

IBD. Instituto Biodinâmico. Matéria Prima permitida para uso em cosméticos naturais e orgânicos certificados. 2006. Available at: www.ibd.com.br. Accessed on: 04 mar. 2008.

IFOAM. International Federation of Organic Agriculture Movements. 2008. Available at: www.ifoam.org. Accessed on: 19 apr. 2008.

MERCK Index. 14ed. Whitehouse Station, 2006.

OLIVEIRA, F.O. Contribuição da análise térmica no desenvolvimento de formulações de batons. São Paulo, 2003. 85 p. [Dissertation of Master degree. Institute of Chemistry. University of São Paulo].

RICHTER, M.; LANNES, S.C.S. Ingredientes usados na indústria de chocolates. Braz. J. Pharm. Sci., v.43, n.3, p.357-369, 2007.

WILLIE, R.L.; LUTTON, E.S. Polymorphism of cocoa butter. J. Am. Oil Chemists'Society, v.43, p.491-496, 1996.

Received for publication on 30 March 2012 Accepted for publication on 07 January 2013 